\title{
Critical Discourse Analysis of the Bombing Attack News: An Analysis of Teun A. van Dijk's Model
}

\author{
Nurul Aini \\ Applied Linguistic Study Department \\ Graduate School of Yogyakarta State University \\ Yogyakarta, Indonesia \\ ainisandanabela@gmail.com
}

\author{
Pratomo Widodo \\ English Language Education Study Program \\ Graduate School of Yogyakarta State University \\ Yogyakarta, Indonesia \\ pratomo@uny.ac.id
}

\begin{abstract}
This paper revealed that the text can be separable from the context. The text bring the certain goals that has created with certain intent. To this end, the opinion rubric in the Jakarta Post was delivered to analyze it. By using CDA approaches as a methodology and Van Dijk's model to analyze the text. Teun A. Van Dijk's model analyzed how the text has reproduced by the writer and how the language used in the text. The findings found that there was other issue that brought by the writer in the text. The writer used some linguistics to emphasize his thought in the text.
\end{abstract} model.

Keywords-Critical Discourse Analysis; Teun A. Van dijk's

\section{INTRODUCTION}

Through the language, people can convey ideas, opinion, their feeling, and so on to others. Nowadays, the definition of language has also evolved namely it is not only as a communication device but also it is a medium giving the influence to others. Thus, the language becomes an important thing in human life either communication device or the process to affect human thought and behavior.

As a device, the language could be used reversed the reality. Language does not only consists of the sentences but also the meaning. Gee [1] said that Language has a magical property: when people speak or write they craft what they have to say to fit the situation or context in which they are communicating. But, at the same time, how they speak or write creates that very situation or context. In other words, discourse can be constructed and arranged through appropriate language based on the speaker or written. Thus, discourse can be constructed and made through appropriate language but also it consists of text and discourse that there is exchange of intent in interpersonal context one another [2]. Hence, the language cannot be analyzed based on its structure but it cannot separable from the context that surrounding it.

Nowadays, Indonesia got the attack that claimed victims either men or women, Islam or other religion. The attack took place in church in Surabaya, East Java. This case was so damn so as people created one hashtag as a resistance for perpetrators of terror, namely \#KamiTidakTakut.

This hashtag was created during the bombing of Thamrin, Central Jakarta in 2016. In [3] said around seven hours after that incident it used in social media more over 110.000 times and quoted by abroad news. Furthermore, another hashtag was appeared after the bombing in Surabaya, East Java on Mei $13^{\text {rd }}$ 2018. \#SurabayaOraWedi became trending in social media which can inspire the spirit of victims and other communities against the bombing attack. Through this hashtag, the victims know that they are not alone. There are many people that condemn of terror. From this hashtag, the people united to revenge the bombing attack by a peaceful discourse. Therefore, the discourse can collect the society into groups. Sometimes, the society in the group is not only gathering but also have the same ideology and stand up for the same things. The text is not arranging by itself but there is context covered it. Therefore, it called Critical Discourse or CDA.

In the past two decades Critical Discourse Analysis or CDA approaches to the media have multiplied. These studies have not only investigated the social and communicative contexts of news and other press but have also related these to a systematic analysis of the structures of media discourse, such as lexicon, syntax, topics, metaphor, coherence, news schemas, and so on. Critical analysis of media discourse has a central place in CDA though it was first introduced in critical communication studies.

The Jakarta Post is one of daily English language newspaper in Indonesia. The Jakarta Post was started as a collaboration between four Indonesian media under the urging of Information Minister Ali Murtopo and politician Jusuf Wanandi [4]. In its posting, there is appeared one interesting topic that referred to that hashtag as a react against the bombing attack. The positive reaction to the bombing attack becomes weird and questioned by the discourse made on the Jakarta Post page. The title was "commentary: are we really not afraid of terrorism? This title doubt the people outlook to try to come up after the bombing attack. There is simple question namely whether is the main purposes of this discourse? May it also increase amount of the readers or there is certain writer's ideology inside the text. In other hands, is there another issue that wanted to reveal by the writer? Hence, the discourse can give to affect the mind of the readers.

Therefore, this paper is written based on that issue. This paper want to analyze how the text is built whether the word choice in the text. Thus, the text becomes the comprehensive discourse and meaningful. As Van Dijk [5] gives proposes linguistic (the text dimension), cognitive and socio-cultural definitions. The text is not only give the word, sentences, and paragraph but how the media express an example with a particular language and certain rhetoric. By Teun A. Van Dijk’s 
paradigm, this paper will be analyzed. Hence, this paper focuses on addressing the following questions: How is the dimensions of text can arrange the discourse in the text?

The goal of this paper is that to probe whether the component that building the text so as the discourse have the main certain and meaningful.

\section{LITERATURE REVIEW}

\section{A. Critical Discourse Analysis}

Discourse analysis describes an interdisciplinary family of methodologies and approaches to the study of language and text that draws variously upon linguistics, literary theory and cultural studies, philosophy of language, sociology and psychology[6]. He continued that it focuses on how social relations, identity, knowledge and power are constructed through written and spoken texts in communities. The prime target of critical discourse analysis is to disclose the hidden ideological and power relations which are embedded in text [7]. In a similar vein, Widdowson's perspective[8] texts can be written or spoken, and must be described in linguistic terms and in terms of their intended meaning. Discourse, on the other hand, as text in context, is defined by its effect. Because critical discourse analysis perceives language as a social practice, it presupposes that it cannot function in isolation, but only within a cultural or social setting [9].

Critical discourse analysis or CDA is an amalgamation of a variety of micro-sociological theories and also theories on society and power based Michael Foucault's definition of power [10]. Tenorio [11] said that analysis in CDA can be topdown, where analysts begin with their understanding of the content; or bottom-up, where the starting point is the linguistic detail. In practice, however, some combination of both is in play. The analyst looks for what is encoded in sentences (i.e. signification) and its interaction with context (i.e. significance).

\section{B. CDA Framework by Teun A. Van Dijk}

Van Dijk [12] define “..... a type of discourse analytical research that primarily studies the way social power abuse, dominance, and inequality are enacted, reproduced, and resisted by text and talk in the social and political context. Van Dijk's framework [13] has provided some illustrations of the categories that he believes to be important in doing CDA studies. He asserts that the main point of the analysis is to show how various ideologies are expressed in various kinds of structures. He proposes linguistic, cognitive and socio-cultural definitions. He first argues that discourse is described at the syntactic, semantic, stylistic and rhetorical levels. Secondly, he adds that it needs to be understood in terms of the interlocutors ${ }^{\text {ee }}$ processes of production, reception and understanding. And, thirdly, he points to the social dimension of discourse, which he understands as a sequence of contextualized, controlled and purposeful acts accomplished in society, namely, a form of social action taking place in a context.

Although, the news is an information source but it does not rule out the possibility to bring inequality, certain ideology and so on. Van Dijk has approached CDA on the basis of understanding ideological structures and social relations of power involved in discourse. There is an argument that news text are controlled by dominant power [14], [15].
Language use, discourse, verbal interaction, and communication belong to the micro-level of the social order Furthermore, it concluded discourse means communicative event, including conversation, written text, and any semiotic or multimedia dimension of signification. Cognition involves mental or memory structures, representations, and process in discourse such as beliefs and emotion. Third, society, includes both microstructures of interactions, as well as societal such group relation, institutions, and political system [16]. Many structures of sentences in the text and talk may influence the way recipient construct their mental models of specific situations, or how they generalize these to form stereotypes or prejudices.

\section{A. Procedure}

\section{RESEARCH DESIGN}

The researcher has selected full text in the Jakarta Post which is posted on Mei $23^{\text {rd }} 2018$. The selected text represents the idea of the writer. The text represented the idea and the issue that be trending in the newspaper, e-news, social media, and so on.

\section{B. Description}

According to Van Dijk, CDA has three dimensions: text, social cognitive, and social context. In order to disassemble the text in the dimension of text, Van Dijk classified the dimension of text into three parts; macrostructure, superstructure, and microstructure.

\section{FINDINGS AND DisCUSSION}

In this section the research questions of the study are answered. It could be highlighted that in order to answer the research questions of the study the text has analyzed by Van Dijk’s model.

\section{A. The dimension of the text; Macrostructure}

In detail, there are points in the parts of dimension of text; in macrostructure, there is topic or theme. The topic in the text is. The data were identified as presented in table 1 as follows:

\section{TABLE I. MACROSTRUCTURE OF THE DIMENSION TEXT}

\begin{tabular}{|l|l|}
\hline Theme/topic & $\begin{array}{l}\text { The theme in the rubric section in the Jakarta post is } \\
\text { "commentary: are we really not afraid of } \\
\text { terrorism?" }\end{array}$ \\
$\begin{array}{l}\text { This theme illustrates the doubts which is shown by } \\
\text { the discourse maker by composing a sentence in the } \\
\text { question form. }\end{array}$ \\
\hline
\end{tabular}

\section{B. The dimension of the text; Superstructure}

Superstructure focuses on the written scheme, namely; introduction, content, and closing so that it becomes a comprehensive text. In this text, it consists of three things: first, the demeanor of Indonesian people against the bombing attack, the suggestion for the government and the society to keep fight and be brave for the perpetrators of bombing attacks. Second, the discourse involves the constitution of terrorism and military 
involvement, and police performance. The third, the discourse involves the perpetrators identity and their community.

In order to make it clear, the superstructure analysis is described into table 2 below:

\section{TABLE II. SUPERSTRUCTURE OF THE DIMENSION TEXT}

\begin{tabular}{|c|c|}
\hline Introduction & $\begin{array}{l}\text { This discourse starts by a clear statement with the } \\
\text { following sentences: } \\
\text { "The message we have sent to whoever is } \\
\text { responsible for a series of deadly terrorist attacks in } \\
\text { our country is loud and clear: We are not afraid." } \\
\text { Furthermore, this sentence reinforced by the other } \\
\text { sentence, namely: } \\
\text { "By telling the terrorist groups "we are not afraid", } \\
\text { we render the attacks worthless". } \\
\text { Repetition of those sentences evidence that society are } \\
\text { not afraid of the terror being perpetrated. How many } \\
\text { times the bombing attack will never make the society } \\
\text { afraid of the terror. }\end{array}$ \\
\hline Content & $\begin{array}{l}\text { Meanwhile, the courage is shown in introduction is } \\
\text { contested with the sentence below: } \\
\text { "But such a campaign may belie our true reactions } \\
\text { to those terrorist attacks, which is exactly what the } \\
\text { terrorist groups want-an overreaction } \\
\text { The magic word (we are not afraid) which can decrease } \\
\text { the sadness and can reinforce the spirit of the victims } \\
\text { has considered trough the word choice in this sentence } \\
\text { such using "an overreaction". } \\
\text { This sentence is followed by the next sentence which } \\
\text { is described into the sample as a reaction of the } \\
\text { government, namely the president's decision involved } \\
\text { the military. By this example, the writer showed his } \\
\text { idea that the government overreaction. According to } \\
\text { him, it is unnecessary act. This decision can be } \\
\text { suspended by optimizing the police. This case can be } \\
\text { shown in the next sentence: } \\
\text { a. "That despite the rising intensity of its attacks, } \\
\text {..." } \\
\text { b. "The police alone can handle the situation". } \\
\text { c. "The police's Densus } 88 \text { elite counterterrorism } \\
\text { squad has actually won kudos from foreign } \\
\text { governments for its ability to weaken Jemaah } \\
\text { Islamiyah (JI) and thwart many attacks plotted by } \\
\text { Jamaah Ansharud Daulah (JAD) militants". } \\
\text { d. "Densus } 88 \text { has killed many suspected terrorists } \\
\text { in many of its deadly raids". }\end{array}$ \\
\hline
\end{tabular}

He gave more than two evidence that the police performance were better. He also added the resistance of the bombing attack was not in military. It showed in the sentence below:

a. "The only problem is that the police are not trained to handle terror inmates".

b. According to Komnas HAM commissioner Choirul Anam, bringing back Koopsusgab to fight terror is nothing but an overreaction

Indirectly, the writer assumed if the police are optimized to handle terror cases then military involvement was not required (a). The writer added another opinion (b). The sentences above did not revealed the connection with the introduction even the topic in the text. The content of the text was not related

\begin{tabular}{|c|c|}
\hline & $\begin{array}{l}\text { with the topic. The content talked about police, the } \\
\text { government decision and military. Hence, the writer } \\
\text { wanted to emphasize there was another treatment } \\
\text { beside the bombing attack. }\end{array}$ \\
\hline Closing & $\begin{array}{l}\text { There were suggestion as a closing discourse, they } \\
\text { were: } \\
\text { "The President should have reviewed his top } \\
\text { security officials rather than drag the military back } \\
\text { into the civilian sphere". } \\
\text { In other words, there was a sentence that given to affect } \\
\text { that the society should think logically and open minded } \\
\text { that it is. In addition, the first suggestion point to the } \\
\text { government. The writer also showed better the real } \\
\text { effort than a hashtag that has become trending in social } \\
\text { media. It means the writer hopes to the reader. The } \\
\text { sentence as follow: } \\
\text { "We should remain united and rational in the face } \\
\text { of terror. We should never be afraid, but it takes } \\
\text { more than a Twitter hashtag to show that we are } \\
\text { not" }\end{array}$ \\
\hline
\end{tabular}

\section{The dimension of the text; Microstructure}

An analysis of the microstructure could be done by semantic, syntax, stylistic, and rhetorical aspects as described in the following table 3 as follows:

\section{TABLE III. MiCROSTRUCTURE OF THE DIMENSION TEXT}

\begin{tabular}{|c|c|}
\hline Semantic & $\begin{array}{l}\text { The bombing attack was not to certain people. Hence, } \\
\text { pronoun in the text was "we" point that it was not only } \\
\text { about the victims but also the society. From the first } \\
\text { sentence until the last sentence the writer consistence to use } \\
\text { this pronoun. Hence, or \#wearenotafraid was not covering } \\
\text { the victims but all society. In addition, the meaning of that } \\
\text { pronoun also emphasized that terror attack not only hurt a } \\
\text { certain group of people with a certain identity the society } \\
\text { of Indonesia whatever the background. }\end{array}$ \\
\hline Syntax & $\begin{array}{l}\text { 1. Cohesion } \\
\text { There were some conjunction that linked one sentence } \\
\text { to other sentences as follows: } \\
\text { a. But; this conjunction used to contradict the sentences. } \\
\text { In the text, this conjunction is found in the sentences } \\
\text { below: } \\
\text { "By telling the terrorist groups "we are not afraid", } \\
\text { we render the attacks worthless". This sentence } \\
\text { contrast with "such a campaign may belie our true } \\
\text { reactions to those terrorist attacks," } \\
\text { b. Therefore; in the sentence below: } \\
\text { "Therefore, the problem was not that the law } \\
\text { enforcers knew about the suicide bombers and were } \\
\text { unable to act but that state intelligence agencies } \\
\text { failed to detect the threat". } \\
\text { This conjunction indicate that it is not about the police } \\
\text { performance but the governments' failure. } \\
\text { c. Meanwhile; In addition, another conjunction also } \\
\text { emphasize that the government fail in avoid the terror } \\
\text { attack. The sentences as follow: } \\
\text { " The Surabaya, meanwhile, were a massive } \\
\text { intelligence failure" }\end{array}$ \\
\hline & $\begin{array}{l}\text { Those conjunctions reveled the contradiction discourse. } \\
\text { The police performance discourse in the first issue and the } \\
\text { government in another one. }\end{array}$ \\
\hline Stylistics & $\begin{array}{l}\text { This text was more than three times used "police, Densus } \\
\text { 88, and military". It indicates the word that related with } \\
\text { them the more important than others. }\end{array}$ \\
\hline
\end{tabular}




\begin{tabular}{|c|c|}
\hline & $\begin{array}{l}\text { Furthermore, the writer prefer to use "the only problem" } \\
\text { than "one of problem" to emphasize that this discourse was } \\
\text { important. }\end{array}$ \\
\hline Rhetoric & $\begin{array}{l}\text { This discourse quote a metaphor style like Nietzsche's } \\
\text { expression: } \\
\text { "Those that do not kill us make us stronger". } \\
\text { Actually, the bombing attack has killed many people. The } \\
\text { victims strong because they united with other people. } \\
\text { In the other hands, this text showed another expression by } \\
\text { using some conjunctions such as but, meanwhile, therefore. } \\
\text { All conjunction in the text revealed the consequences of the } \\
\text { bombing attack. They did not response the attack but the } \\
\text { effect of it. }\end{array}$ \\
\hline
\end{tabular}

\section{CONCLUSION}

This paper confirmed that the discourse analysis can be done by the critical discourse analysis method. One of the paradigm was from Teun A. Van Dijk. The text can be analyzed by the Van Dijk's model. In his thought, the text can be separable from the context that covered it.

Another fact revealed that the text can affect for the reader. Hence, the reader think and act appropriate with the writer. By Van Dijk's model, this text consisted of macrostructure, superstructure, and microstructure. To affect the reader, the writer gave the topic that is not related with the content, gave many examples in the text that were not related to the topic and so on. This aimed to get more support from the reader. In the fact, the writer elected the topic in the question sentence to show another one. That was not about the bombing attack but the government decision.

To support it, the writer gave the government's failure and the police performance as a comparison. So that way, the text was not about the hashtag but the text talked about the decision government. The hashtag news just be the device to communicate the writer's thought.

\section{ACKNOWLEDGMENT}

The researchers wanted to deliver his great thanks to God for His bless and kindness. It's His endless that make the researchers possible to complete this paper. The researchers also wanted to express the sincere than to all who has given the contribution for the researchers. Personally, we realize that we could not complete it well without them.

\section{REFERENCES}

[1] J. P. Gee, An introduction to Discourse Analysis Theory and Method, London and New York: Routledge, 1999.

[2] M. A. K. Halliday, Language as A Social Semiotic, London: University Press. 1978.

[3] "Serangan Jakarta: Pesan kuat untuk pelaku teror \#KamiTidakTaku [Jakarta Attack: Strong message for terrorist \#KamiTidakTakut],” BBC News Indonesia, January 14, 2016. [Online]. Available: https:/www.bbc.com/indonesia/majalah/2016/01/160114_tre nsosial_kamitidaktakut.

[4] “The Jakarta Post," Wikipedia. [Online] Available: https://en.wikipedia.org/wiki/The_Jakarta_Post.

[5] T. A. van Dijk, "Discourse as Interaction in Society." in Discourse as Social Interaction, vol 2, T. A. van Dijk, Ed. London: Sage, 1997, pp. 137.

[6] A. Luke, "Theory and Practice in Critical Discourse Analysis," Int. Encyclop. of the Soc. of Educat., Elsevier Science.

[7] R. Elahe and M. Sharififar, "Critical Discourse Analysis and Its Implication in English Language Teaching: A case study of Political Text," Theo. and Prac. in Lang. Stud., vol. 5, no. 3, pp. 504-511, 2015.

[8] H. G. Widdowson, Text, Context, Pretext: Critical Issues in Discourse Analysis, Oxford: Blackwell, 2004.

[9] E. Tarone, "Critical Discourse Analysis as an Interdisciplinary Research Methodology for Interdisciplinary, Intercultural and an Inter-Institutional Assessment Tool for Student-Perceived Learning Compared with Instructor-Perceived Teaching of Interdisciplinary Online Courses," Procedia-Soc. and Behav. Sci., pp. 278-283, 2015.

[10] E. H. Tenorio, "Critical Discourse Analysis: An Overview," Nordic J. of Engl. Stud., vol. 10, no. 1, 2011

[11] F. Rahimi and M. J. Riasati, "Critical Discourse Analysis: Scrutinizing Ideologically-Driven Discourses," Int. J. of Human. and Soc. Sci., vol. 1, no. 6, 2011.

[12] T. van Dijk, "Multidisciplinary CDA," in Methods of critical discourse analysis, R. Wodak and M. Meyer. Great Britain: SAGE Publications, 2001.

[13] T. A. van Dijk, Discourse as structure and process of discourse studies: A multidisciplinary introduction, vol. I. London: SAGE Publications, 1997.

[14] T. A. van Dijk, The handbook of discourse analysis, 2nd ed. John Wiley \& Sons Inc., 2015.

[15] C. Faerch and G. Kasper, "Two Ways of Defining Communication Strategies,” Lang. Learn., vol. 34, no. 1, pp. 45-63, 1984.

[16] M. Jahedi and F. S. Abdullah, "An Overview of Focal Approaches of Critical Discourse Analysis," Int. J. of Edu. \& Lit. Stud., vol. 2, no. 4, pp. 29-36, 2014. 
